\title{
Pengaruh Variasi Lebar Sudu Mangkok terhadap Kinerja Turbin Kinetik Poros Vertikal
}

\author{
Ujiburrahman $^{1 *}$, Rudy Soenoko ${ }^{2}$, Moch. Agus Choiron ${ }^{3}$ \\ Jurusan Teknik Mesin, Fakultas Teknik, Universitas Brawijaya ${ }^{1,2,3}$ \\ Jl. Veteran Malang, Ketawanggede, Kec. Lowokwaru, Kota Malang, Jawa Timur, Indonesia \\ Email: ujienergy@student.ub.ac.id¹, rudysoenoko123@yahoo.com², \\ moch.aguschoiron123@yahoo.com³
}

\begin{abstract}
Abstrak
Daya dan efisiensi merupakan parameter-parameter yang menjadi tolak ukur dari kinerja sebuah turbin kinetik. Penelitian sebelumnya menunjukan berbagai faktor seperti debit aliran, dimensi dan geometri dari turbin kinetik adalah varaibel-variabel yang mempengaruhi besarnya daya dan efisiensi. Dalam upaya meningkatkan kinerja turbin kinetik dibutuhkan pemahaman yang mendalam terhadap faktor-faktor yang mempengaruhinya. Oleh karena itu tujuan dari penelitian ini adalah untuk mengetahui pengaruh variasi lebar sudu mangkok terhadap kinerja turbin kinetik. Metode yang digunakan dalam penelitian ini adalah eksperimental nyata pada skala laboratorium. Pengujian dilakukan pada turbin kinetik poros vertikal dengan variasi lebar sudu $8 \mathrm{~cm}, 9 \mathrm{~cm}$ dan $10 \mathrm{~cm}$. Setiap turbin diuji pada variasi debit air $45 \mathrm{~m}^{3} / \mathrm{h}, 50 \mathrm{~m}^{3} / \mathrm{h}, 55 \mathrm{~m}^{3} / \mathrm{h}, 60 \mathrm{~m}^{3} / \mathrm{h}$ dan $65 \mathrm{~m}^{3} / \mathrm{h}$ dan variasi putaran $20 \mathrm{rpm}, 40 \mathrm{rpm}, 60$ rpm, $80 \mathrm{rpm}$, dan $100 \mathrm{rpm}$. Hasil penelitian menunjukkan bahwa lebar sudu mangkok mempengaruhi kinerja dari turbin kinetik dimana lebar sudu mangkok $10 \mathrm{~cm}$ memiliki kinerja lebih tinggi dari lebar sudu mangkok $8 \mathrm{~cm}$ dan $9 \mathrm{~cm}$. Kinerja tertinggi turbin kinetik pada variasi lebar sudu mangkok $10 \mathrm{~cm}$ diperoleh pada kondisi putaran $80 \mathrm{rpm}$ dan debit $65 \mathrm{~m}^{3} / \mathrm{h}$. Pada kondisi tersebut daya yang dihasilkan oleh turbin kinetik adalah 12,98 Watt dan efisiensinya $35,72 \%$.
\end{abstract}

Kata kunci: Daya turbin, lebar sudu, efisiensi turbin, turbin kinetik.

\section{Pendahuluan}

Perkembangan teknologi menjadikan energi sebagai kebutuhan mendasar dalam mobilitas kegiatan manusia. Diperkirakan kebutuhan terhadap energi terus meningkat sekitar dua sampai tiga kali dalam kurun waktu sepuluh tahun. Seperti diketahui bahwa penyuplai terbanyak terhadap kebutuhan energi saat ini baik di dunia maupun di Indonesia adalah bersumber dari energi fosil. Sementara itu produksi energi fosil khususnya minyak bumi tidak bisa ditingkatkan secara signifikan karena ketersediaannya semakin terbatas. Di sisi lain, penggunaan energi baru terbarukan belum optimal sedangkan potensinya sangat besar.

Jika konsumsi energi dibagi berdasarkan kebutuhan jenis energi maka sebagian besar konsumsi energi di
Indonesia dipakai dalam bentuk pembakaran dan listrik. Diketahui bahwa pada tahun 2016 sumber pembangkit energi listrik sebagian besar berasal dari energi fosil yaitu sebesar $90 \%$ dari keseluruhan pembangkit listrik yang ada. Sementara sisanya bersumber dari beberapa energi terbarukan seperti energi panas bumi, energi air, dan energi angin [1].

Dari dominasi pemakaian energi fosil maka saat ini Indonesia melalui kementrian ESDM berusaha mengoptimalkan pengembangan Energi Baru Terbarukan (EBT) sebagai penyedia energi nasional. Salah satu energi terbarukan yang potensial di Indonesia adalah enrgi air. Energi air merupakan sumber energi yang bersih dan ramah lingkungan. Di dunia secara umum pembangunan bendungan tidak begitu sederhana karena tingginya biaya investasi, dampak pada ekosistem dan banyak 
kendala lainnya telah menjadi penghambat pengembangan pembangkit listrik tenaga air. Kendala yang sama juga terjadi di Indonesia, hal ini dapat dilihat dari fakta bahwa potensi tenaga air untuk PLTA dan PLTMH tersebar di Indonesia dengan total perkiraan sampai $75.000 \mathrm{MW}$, sementara pemanfaatannya masih sekitar $9 \%$ dari total potensi [1].

Kesulitan pembangunan bendungan telah menyebabkan kecenderungan pemanfaatan energi gerak yang dihasilkan langsung dari aliran air untuk pembangkit listrik. Namun, laju aliran pada umumnya rendah. Oleh karena itu, ada kebutuhan untuk mendesain turbin yang sesuai untuk kecepatan yang relatif rendah. Salah satu perangkat pembangkit energi yang sesuai saat ini adalah turbin kinetik, turbin jenis ini mampu untuk mengkonversi potensi energi yang tersimpan dalam aliran dengan kecepatan $0,01-2,8 \mathrm{~m} / \mathrm{s}$ menjadi energi listrik $[3,4]$.

Selain sesuai dengan keadaan energi yang tersedia, penggunaan turbin kinetik juga sangat menguntungkan ditinjau dari pengaplikasian praktis karena memiliki bentuk yang sederhana, mudah dibuat dan pemeliharaan. Namun turbin kinetik masih memiliki kekurangan seperti putaran tidak stabil yang menyebabkan daya dan efisiensi yang dihasilkan rendah [5]. Untuk itu banyak penelitian yang telah dilakukan untuk mengetahui berbagai faktor yang mempengaruhi kinerja turbin kinetik.

Fenomena-fenomena yang dijelaskan pada penelitian sebelumnya diantara lain adalah pengaruh jumlah sudu mangkok terhadap kinerja turbin kinetik [3,6,7]. Hasil yang diperoleh menujukkan semakin banyak jumlah sudu maka kinerja dari turbin kinetik akan meningkat. Bertambah panjangnya sudu dan besar debit aliran pada saluran turbin akan meningkatkan kinerja turbin kinetik [8]. Penelitian ini juga menjelaskan peningkatan kinerja turbin terjadi karena adanya penambahan massa aliran yang menumbuk sudu turbin sehingga gaya tangensial yang dihasilkan meningkat dan gaya tangensial tersebut mempengaruhi torsi, daya dan efisiensi turbin kinetik. Perbedaan sudut input pada sudu mangkok dan sudut sudu mangkok juga berpengaruh terhadap kinerja turbin kinetik $[9,10]$. Kinerja turbin dengan sudut input sudu mangkok $10^{\circ}$ lebih tinggi daripada $15^{\circ}$ dan $20^{\circ}$. Semakin kecil sudut input sudu mangkok, kelengkungan sudu semakin besar, sehingga semakin besar pula gaya tangesial, torsi, daya dan efisiensinya. Kinerja turbin kinetik maksimum terjadi pada sudut sudu mundur $15^{\circ}$ dibandingkan dengan variasi sudut sudu yang lain. Pemakaian bentuk sudu yang berbeda juga mempengaruhui karakteristik daya dan efisiensi turbin [11,12]. Daya maksimum yang dibangkitkan dan efisiensi maksimum turbin dengan sudu mangkok lebih besar dibandingkan dengan turbin dengan sudu setengah silinder. Namun perbedaan yang diperoleh relatif kecil atau cenderung sama. Penelitian tentang pengaruh sudut pengarah aliran terhadap kinerja turbin kinetik $[3,13]$. Hasil pengujian menunjukan kinerja teringgi diperoleh pada sudut pengarah aliran yang terbesar yaitu $35^{\circ}$. Secara keseluruhan dalam rentan variasi sudut pengarah yang diuji dalam penelitian, dapat disimpulkan bahwa semakin besar sudut pengarah aliran maka kinerja turbin kinetik semakin baik.

Berdasrakan hasil penelitianpenelitian di atas dapat dikemukakan bahwa berbagai faktor seperti debit aliran, dimensi dan geometri dari turbin kinetik adalah varaibel-variabel yang mempengaruhi kinerja dari sebuah turbin kinetik. Dalam upaya meningkatkan kinerja turbin kinetik dibutuhkan pemahaman yang mendalam terhadap faktor - faktor yang mempengaruhinya. Pengggunaan sudu bentuk mangkok dapat memperbesar gaya tangensial yang akan meningkatkan kinerja turbin kinetik. Sementara itu kinerja turbin kinetik jenis sudu mangkok itu sendiri dapat ditingkatkan dengan menambah masa aliran air yang menumbuk sudu turbin.

Oleh karena itu tujuan penelitian ini adalah untuk mengetahui pengaruh variasi lebar sudu mangkok terhadap kinerja turbin 
kinetik poros vertikal. Parameter yang diteliti adalah daya dan efisiensi yang dihasilkan turbin. Penambahan ukuran lebar sudu mangkok diharapkan dapat memperbesar masa aliran atau atau meningkatkan momentum air yang menumbuk sudu-sudu turbin.

\section{Tinjauan Pustaka}

\section{Turbin air}

Turbin air adalah salah satu mesin penggerak yang mana fluida kerjanya adalah air. Turbin air mengubah energi potensial air menjadi energi mekanis dengan memanfaatkan ketinggian air yang dinamakan head. Untuk pemanfaatan energi air dibutuhkan bangunan air yang khusus. Perbedaan antara permukaan air diperoleh dengan membangun suatu dam, dimana ketinggian air akan bergantung pada kondisi dan tempat. Pada sungaisungai dataran rendah, biasanya ditempatkan dekat rumah turbin, sedangkan pada sungai-sungai dataran tinggi dam dibuat dengan jarak tertentu dari rumah turbin. Air smpai ke turbin melalui saluran yang disebut pipa pesat [14].

\section{Turbin kinetik}

Turbin kinetik adalah salah satu penggerak mula yang dapat menghasilkan energi mekanik berupa putaran poros dengan memanfaatkan kecepatan aliran air dari sungai yang memiliki energi kinetik. Energi kinetik air selanjutnya diubah menjadi energi mekanis pada turbin yang digunakan untuk menggerakkan generator sehingga membangkitkan energi listrik. Turbin kinetik sangat tepat untuk dipakai pada daerah yang datar yang memiliki aliran sungai terutama daerah pedesaan. Sampai saat ini dikenal dua jenis turbin kinetik yaitu turbin kinetik dengan poros horisontal dan turbin kinetik berporos vertikal [10].

\section{Prinsip kerja turbin kinetik}

Turbin kinetik memanfaatkan kecepatan aliran air yang mengalir melewati sudu-sudu turbin. Perubahan momentum air yang melewati sudu-sudu turbin dapat memberikan gaya dorong pada sudu-sudu sehingga runner berputar. Perputaran dari runner mengakibatkan perubahan energi kinetik air menjadi energi mekanis pada poros turbin yang kemudian digunakan untuk menggerakkan generator sehingga membangkitkan energi listrik. Parameter yang menunjukkan kinerja turbin kinetik adalah daya dan efisiensi turbin. Adapun besarnya nilai daya dan efisiensi dari turbin kinetik dapat ditentukan dengan persamaan 1 dan 2.

Daya yang dihasilkan turbin kinetik merupakan daya air yang bisa dimanfaatkan atau dikonversi menjadi energi mekanik pada poros.

$$
\begin{aligned}
& P_{t}=T . \omega \\
& \mathrm{T}=\mathrm{F}_{\mathrm{t}} \cdot \mathrm{R} \\
& \omega=\frac{2 \cdot \pi \cdot n}{60}
\end{aligned}
$$

Keterangan:

$$
\begin{aligned}
& P_{t}=\text { Daya turbin }(\text { Watt }) \\
& T=\text { Torsi }(\mathrm{N} / \mathrm{m}) \\
& \omega=\operatorname{Kecepatan} \text { anguler }(\text { Radian } / \mathrm{s}) \\
& R=\text { Radius pully }(\mathrm{m}) \\
& n=\text { Putaran poros atau roda turbin } \\
& \quad \text { (rpm) } \\
& F_{t}=\text { Gaya tangensial }(\mathrm{N})
\end{aligned}
$$

Efisiensi turbin kinetik ditentukan oleh perbanding anantar daya air yang masuk dengan besarnya daya yang dihasilkan dari turbin knetik.

$$
\eta=\frac{P_{t}}{P_{a}} \times 100 \%
$$

Keterangan:

$$
\begin{aligned}
& \eta=\text { Efisiensi }(\%) \\
& P_{t}=\text { Daya turbin (Watt) } \\
& P_{a}=\text { Daya air (Watt) }
\end{aligned}
$$

Sementara itu untuk menghitung besarnya daya air yang tersedia pada aliran digunakan persamaan sebagai berikut.

$$
P_{a}=\frac{1}{2} \cdot \rho \cdot A \cdot v^{2}
$$

Keterangan:

$$
\begin{aligned}
& P_{a}=\text { Daya air }(\text { Watt }) \\
& \rho=\text { Massa jenis air }\left(\mathrm{Kg} / \mathrm{m}^{3}\right) \\
& A=\text { Luas ujung saluran }(\mathrm{A})
\end{aligned}
$$




\section{Metode Penelitian}

\section{Variabel Penelitian}

1. Variabel bebas : Variasi lebar sudu (8 $\mathrm{cm}, 9 \mathrm{~cm}$ dan $10 \mathrm{~cm})$, debit air : $(45,50$, 55,60 dan $65 \mathrm{~m}^{3} / \mathrm{jam}$ ) dan putaran turbin ( 100, 80, 60, 40, 20 dan $0 \mathrm{rpm}$ ).

2. Variabel terikat yang diamati dalam penelitian ini adalah daya dan efisiensi turbin.

3. Variabel terkontrol : Jumlah sudu 8 bilah, Sudut sudu dikondisikan konstan pada posisi $15^{\circ}$ mundur seperti ditunjuk pada gambar 2, Kedalaman sudu dikondisikan pada $20 \mathrm{~mm}$. Sudut pengarah aliran $10^{\circ}$ dan sudut kemiringan sluran $4^{\circ}$.

\section{Tempat dan waktu penelitian}

Penelitian ini dilaksanakan di laboratorium Fluida Fakultas Tehknik Univesitas Brawijaya. Waktu penelitian selama 1 bulan dimulai pada bulan Maret 2019 sampai dengan April 2019.

Alat dan bahan penelitian

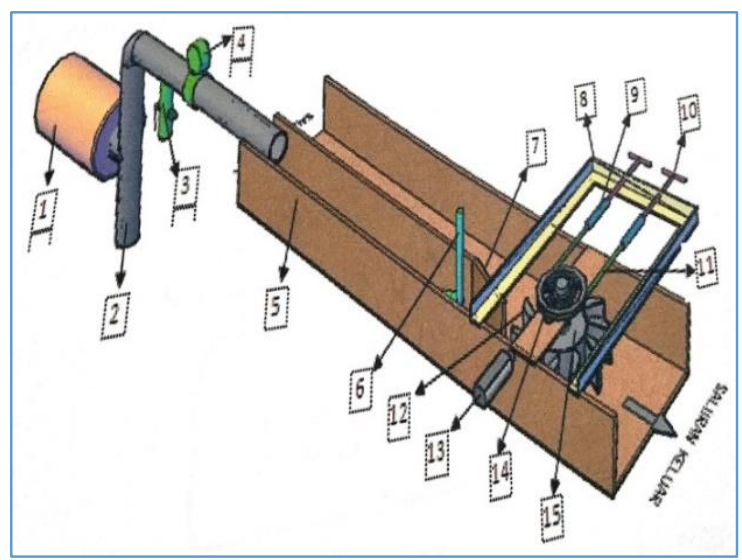

Gambar 1. Instalasi pengujian turbin kinetik.

Keterangan gambar:

1. Pompa

2. Pipa alir

3. Katup buangan

4. Flowmeter

9. Neraca pegas

5. Saluran turbin

10. Tuas penetel

6. Flowatch

7. Pengarah aliran

8. Dudukan tuas penetel gaya gaya

11. Tali

12. Sudu turbin

13. Tachometer

14. Puli

15. Cakram / Roda turbin

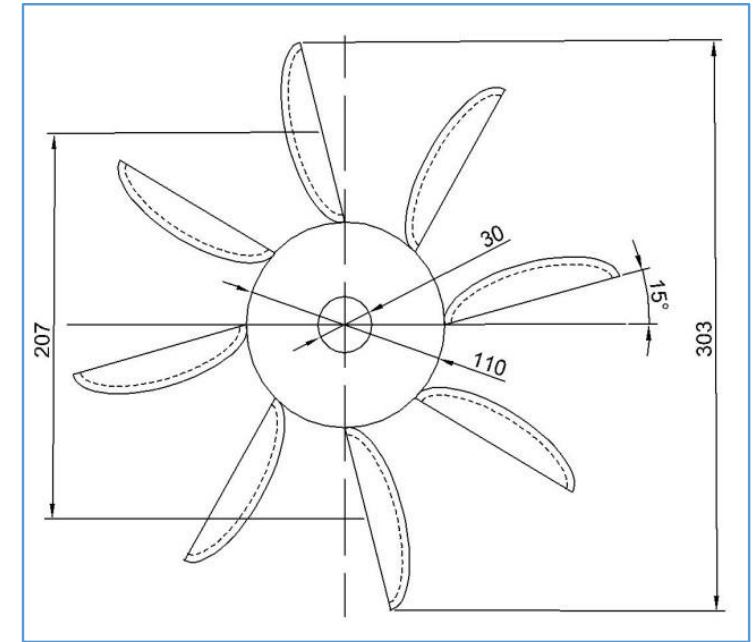

(a)

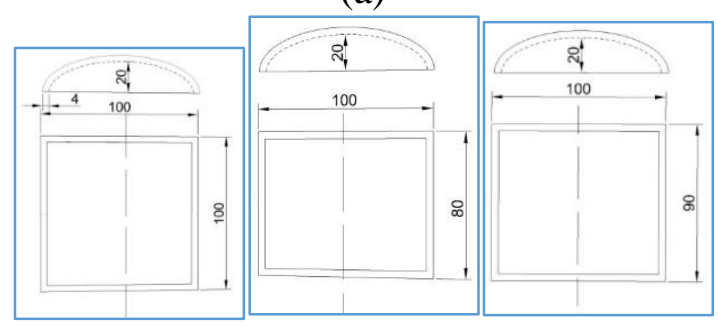

(b)

Gambar 2. Dimensi runner turbin kinetik ditunjukan oleh gambar (a). Gambar (b) menunjukan dimensi sudu. (Satuan gambar dalam mili meter)

\section{Prosedur pengujian}

1. Membuat tabel untuk mencatat hasil pengujian,

2. Memasang dan mengatur semua instalasi penelitian sesuai dengan yang telah direncanakan,

3. Memeriksa kondisi perangkat seperti pompa dan alat-alat ukur untuk siap digunakan,

4. Mengatur debit aliran dengan cara memutar kran sesuai dengan variasi debit yang direncanakan,

5. Mengukur putaran poros turbin dengan alat ukur tachometer tanpa beban terlebih dahulu. Kemudian mengukur putaran poros turbin dengan beban yang diberikan secara pelan - pelan dengan cara memutar tuas penyetel beban gaya sampai memenuhi nilai putaran yang divariasikan. Mencatat data putaran (n), gaya (F) dan debit (Q) setiap variasi pengukuran putaran turbin,

6. Melakukan tiga kali pengulangan pada setipa variabel yang divariasikan, 
7. Mengulang langkah 4 sampai dengan ke 7 untuk setiap variasi yang telah direncanakan.

\section{Hasil dan Pembahasan}

\section{Daya turbin}

Bagian ini akan dibahas tentang daya yang dihasilkan turbin berdasarkan grafik hubungan antara putaran dan daya turbin. Secara umum dari persamaan 1 terlihat bahwa Daya turbin sangat tergantung pada besarnya torsi dan kecepatan anguler, dimana daya turbin dapat ditingkatkan dengan meningkatkan nilai torsi dan atau kecepatan anguler. Sementara itu dalam sistem operasi kerja turbin kinetik, torsi dan kecepatan anguler menunjukan hubungan yang berbanding terbalik dimana torsi yang tinggi diperoleh dari pembebanan yang besar. Akan tetapi besarnya pembebanan mengakibatkan turunnya putaran dan itu artinya kecepatan anguler yang dihasilkan akan kecil.

Dari pemahaman di atas maka dibutuhkan kondisi pembebanan pada poros dan putaran turbin yang proporsional untuk memperoleh operasi kerja daya turbin yang optimal. Dalam penelitian ini telah dilakukan pengujian putaran untuk setiap debit air pada masing-masing turbin dengan variasi lebar sudu mangkok.

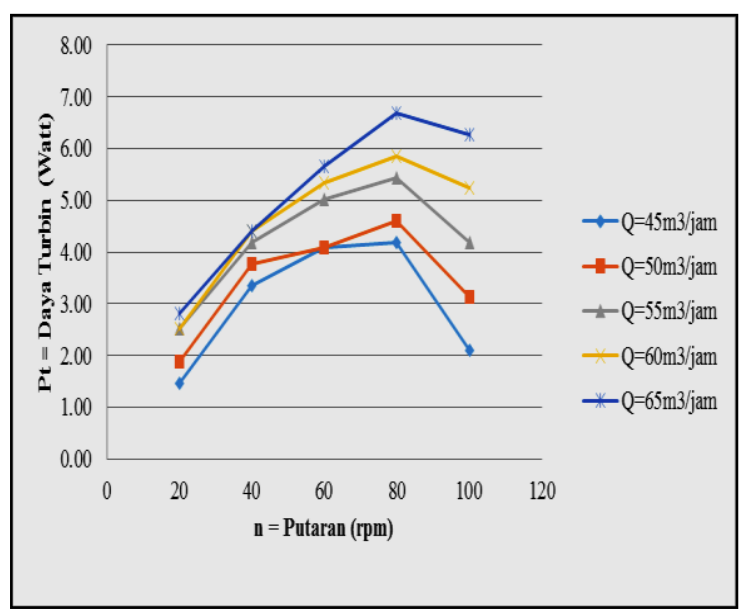

(a)

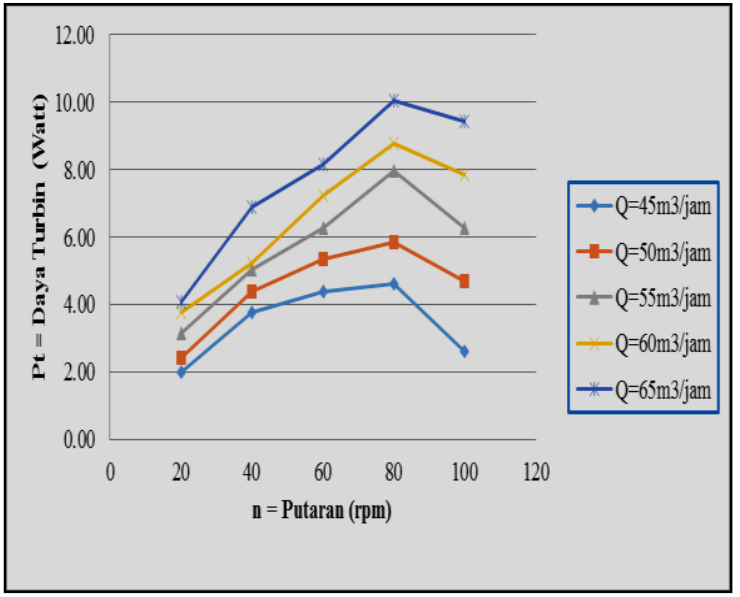

(b)

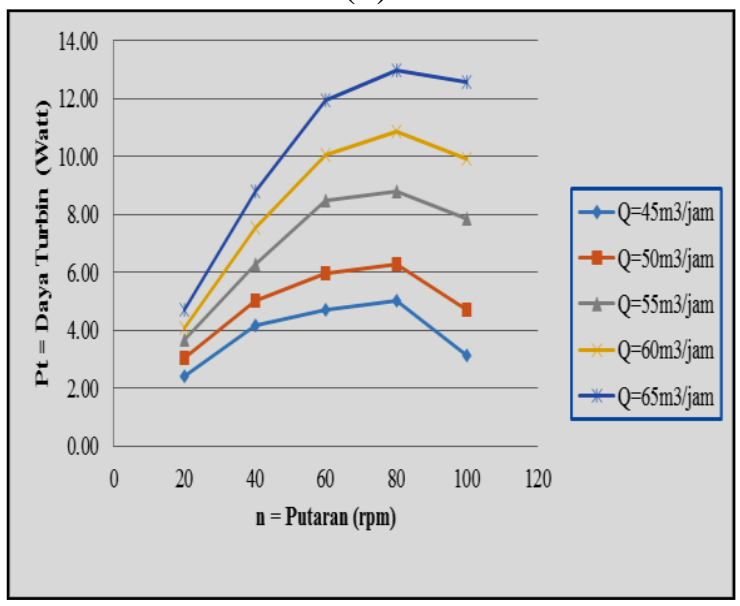

(c)

Gambar 3. Grafik hubungan antara debit dan daya pada setiap putaran (a) untuk lebar sudu $8 \mathrm{~cm}$ (b) lebar sudu $9 \mathrm{~cm}$ dan (c) lebar sudu $10 \mathrm{~cm}$.

Grafik pada gambar 3 memperlihatkan fenomena hubungan putaran dan daya turbin yang identik untuk setiap debit aliran begitupun dengan masing-masing variasi lebar sudu $8 \mathrm{~cm}, 9$ $\mathrm{cm}$, dan $10 \mathrm{~cm}$. Secara keseluruhan meningkatnya putaran atau berkurangnya pembebanan akan meningkatkan daya turbin. Fenomena ini bisa terjadi karena adanya aliran balik dari air yang menumbuk sudu bila pembebanannya besar. Momentum aliran diduga memberi gaya yang berlawanan terhadap kecepatan absolut fluida. Putaran turbin yang rendah juga menahan aliran air disekitar sudu turbin dan memberi pembebanan yang berlawanan dengan arah torsi.

Meski demikian secara keseluruh namun pada pengujian putaran tertinggi 
dalam skala penelitian ini menunjukkan penurunan daya yang dihasilkan turbin. Fenomena ini terjadi karena pada saat putaran tanpa pembebanan maka torsi sama dengan nol oleh karena itu daya yang dihasilkan dari turbin juga sama dengan nol. Oleh karena itu putaran 100 rpm mendekati putaran puncak dari turbin tanpa pembebanan itu artinya torsi mendekati nol. Grafik pada gambar 3 memperlihatkan turbin dengan lebar sudu 8 $\mathrm{cm}$ menghasilkan daya tertinggi pada putaran $80 \mathrm{rpm}$ yaitu sebesar 6,70 Watt pada debit $65 \mathrm{~m}^{3} / \mathrm{h}$ dan daya terendah pada putaran $20 \mathrm{rpm}$ yakni 1,47 Watt pada debit $45 \mathrm{~m}^{3} / \mathrm{h}$. Sedangkan turbin dengan variasi lebar sudu $9 \mathrm{~cm}$ menghasilkan daya terbesar pada putaran $80 \mathrm{rpm}$ yaitu sebesar 10,05 Watt pada debit $65 \mathrm{~m}^{3} / \mathrm{h}$ dan daya terkecil pada putaran $20 \mathrm{rpm}$ yakni 1,99 Watt pada debit $45 \mathrm{~m}^{3} / \mathrm{h}$. Sementara itu daya maksimum yang dihasilkan turbin dengan variasi lebar sudu $10 \mathrm{~cm}$ diperoleh pada putaran $80 \mathrm{rpm}$ yaitu sebesar 12,98 Watt pada debit $65 \mathrm{~m}^{3} / \mathrm{h}$ dan daya minimum pada putaran $20 \mathrm{rpm}$ yakni 2,41 Watt pada debit $0.013 \mathrm{~m}^{3} / \mathrm{h}$.

Adapun variabel debit air memberikan nilai daya turbin yang semakin tinggi seiring dengan meningkatnya debit. Fenomena ini bisa dipahami dari persamaan untuk menentukan daya air. Peningkatan debit air akan meningkatkan kecepatan air kemudian meningkatkan kecepatan anguler dan memperbesar massa aliran yang menumbuk sudu kemudian memperbesar gaya.

Secara keseluruhan dari tiga variasi lebar sudu yang diuji, daya tertinggi diperoleh pada turbin dengan lebar sudu 10 $\mathrm{cm}$, diikuti turbin dengan variasi lebar $9 \mathrm{~cm}$ dan daya terendah diperoleh pada turbin dengan lebar sudu $8 \mathrm{~cm}$. Pada skala dimensi sudu yang diuji dapat dikatakan bahwa semakin besar lebar sudu maka daya turbin akan meningkat pula. Pada nilai debit aliran yang sama lebar sudu yang lebih besar menghasilkan daya yang lebih tinggi. Hal ini menunjukan energi potensial dari aliran air dapat dimanfaatkan lebih banyak pada turbin dengan variasi lebar sudu yang lebih besar. Secara teoritis besarnya energi potensial air bergantung pada nilai kecepatan dan masa aliran, tentu saja pada debit air yang sama kecepatan aliran juag sama. Oleh karena itu energi potensial yang dimanfaatkan pada fenomena ini bukan dari kecepatan melainkan penambahan masa aliran yang menumbuk sudu disebabkan luasan sudu lebih besar.

\section{Efisiensi turbin}

Dari persamaan 4 nilai efisiensi adalah besarnya daya air (Pa) dibagi daya turbin $(\mathrm{Pt})$. Dengan kata lain hubungan yang diberikan dari persamaan 4 adalah jika daya turbin bertambah untuk kondisi daya air yang sama maka efisiensi dari turbin juga meningkat. Sementara itu dari persamaan 5 menunjukan bahwa parameter daya air itu sendiri bergantung pada debit air. Oleh karena itu pembahasan bagian ini akan berdasarkan kepada grafik hubungan antara debit dan efisiensi. Dengan demikian untuk memahami secara keseluruhan efisiensi dari turbin pada operasi kerja turbin kinetik dalam penelitian ini, maka berikut ditampilkan grafik hubungan antara putaran terhadap efisiensi turbin untuk setiap debit air pada masing-masing turbin dengan variasi lebar sudu.

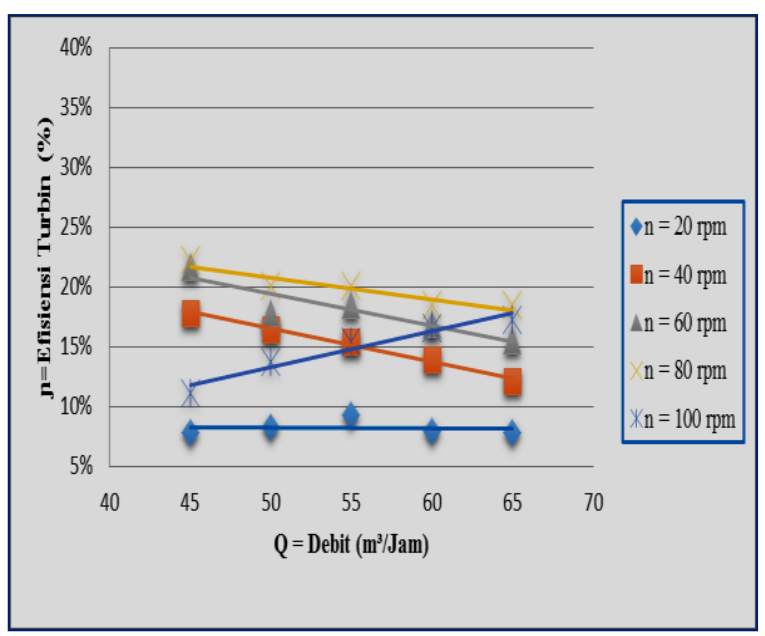

(a) 


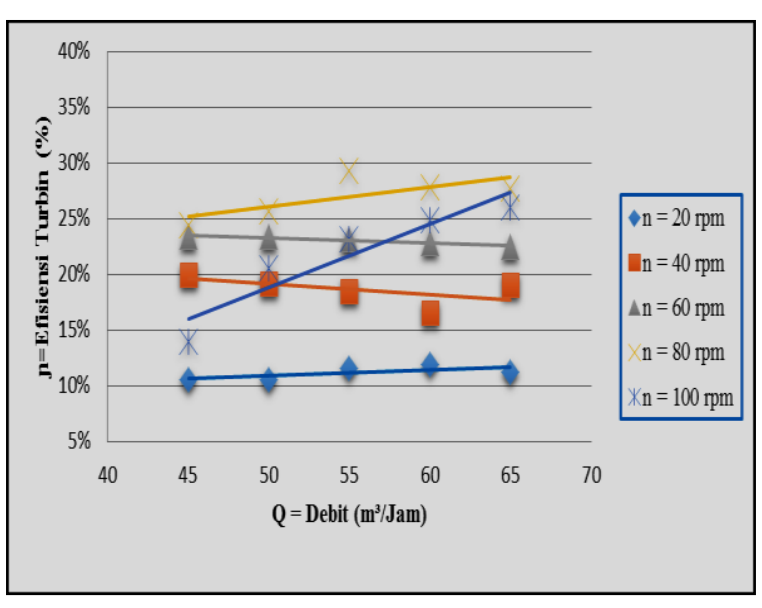

(b)

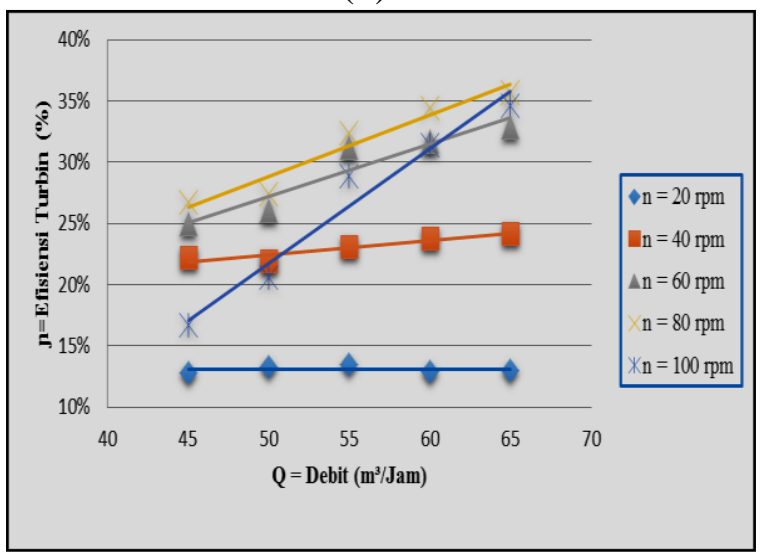

(c)

Gambar 4. Grafik hubungan antara putaran dan efisiensi pada setiap debit untuk (a) lebar sudu $8 \mathrm{~cm}$, (b) lebar sdu $9 \mathrm{~cm}$ dan (c) lebar sudu $10 \mathrm{~cm}$.

Pada gambar 4 terlihat bahwa fenomena yang identik dari hubungan antara debit air terhadap efisiensi pada setiap putaran yang diuji untuk turbin dengan variasi lebar sudu $8 \mathrm{~cm}$ dan $9 \mathrm{~cm}$. Dimana meningkatnya debit air yang diberikan maka efisiensi turbin akan menurun. Sedangkan turbin dengan variasi lebar sudu $10 \mathrm{~cm}$ menunjukkan hal yang sebaliknya yaitu efisiensi yang dihasilkan semakin meningkat seiring dengan naiknya putaran turbin. Hal ini terjadi karena bertambahnya debit air juga memperbesar luasan aliran. Karena itu turbin dengan sudu yang lebih lebar akan memperoleh masa aliran tambahan dari naiknya debit air. Dengan kata lain momentum yang lebih besar akan meningkatkan daya yang dihasilkan turbin. Meski daya air terus meningkat namun turbin dengan lebar sudu
$8 \mathrm{~cm}$ dan $9 \mathrm{~cm}$ tidak bisa mengoptimalkan energi potensial dari aliran yang bertambah. Sementara itu turbin dengan variasi lebar 10 $\mathrm{cm}$ bisa mengoptimalkan daya air yang tersedia. Secara teoritis efisiensi merupakan perbandingan antara daya turbin dan daya air. Berdasarkan pengetahuan tersebut maka fenomena ini menunjukan bahwa turbin dengan lebar sudu yang lebih besar bisa mengoptimalkan daya air yang tersedia.

Grafik pada gambar 4 menunjukkan turbin dengan lebar sudu $8 \mathrm{~cm}$ menghasilkan efisiensi tertinggi pada putaran $80 \mathrm{rpm}$ yaitu sebesar $18,44 \%$ pada debit $45 \mathrm{~m}^{3} / \mathrm{h}$ dan efisiensi terendah pada putaran 20 rpm yakni 7,78\% pada debit 45 $\mathrm{m}^{3} / \mathrm{h}$. Sedangkan turbin dengan variasi lebar sudu $9 \mathrm{~cm}$ menghasilkan efisiensi terbesar pada putaran $80 \mathrm{rpm}$ yaitu sebesar $29,27 \%$ pada debit $65 \mathrm{~m}^{3} / \mathrm{h}$ dan efisiensi terkecil pada putaran $20 \mathrm{rpm}$ yakni 10,56\% pada debit $45 \mathrm{~m}^{3} / \mathrm{h}$. Sementara itu daya maksimum yang dihasilkan turbin dengan variasi lebar sudu $10 \mathrm{~cm}$ diperoleh pada putaran $80 \mathrm{rpm}$ yaitu sebesar $35,72 \%$ pada debit $65 \mathrm{~m}^{3} / \mathrm{h}$ dan daya minimum pada putaran $20 \mathrm{rpm}$ yakni 12,78\% pada debit 45 $\mathrm{m}^{3} / \mathrm{h}$.

Efisiensi maksimum terjadi pada turbin dengan lebar sudu $10 \mathrm{~cm}$, dikuti variasi lebar $9 \mathrm{~cm}$ dan daya terendah diperoleh pada lebar sudu $8 \mathrm{~cm}$. Dengan kata lain hasil penelitian menunjukkan semakin besar lebar sudu maka efisiensi turbin akan meningkat pula. Pada nilai debit aliran yang sama turbin dengan lebar sudu yang lebih besar menghasilkan efisiensi yang lebih tinggi. Hal ini terjadi karena adanya peningkatan daya turbin pada daya air yang sama. Disebabkan adanya energi potensial dari aliran air dapat dimanfaatkan lebih banyak pada turbin dengan lebar sudu yang lebih besar. Secara teoritis efisiensi turbin merupakan perbandingan antara daya turbin dengan dengan daya potensial air yang tersedia. Karena itu efisiensi yang lebih tinggi pada turbin dengan variasi lebar sudu yang lebih besar dapat dipahami karena pada bagian sebelumnya daya turbin 
yang lebih tinggi juga didapatkan pada turbin dengan variasi lebar sudu yang lebih besar.

Hubungan atara debit air dan efisiensi turbin memperlihatkan pola yang berbeda pada masing-masing turbin dengan variasi lebar sudu. Fenomena ini terjadi karena kondisi aliran yang berada pada saluran terbuka dimana bertambahnya debit air menyebabkan luasan aliran membesar. karena itu ada kondisi tertentu yang sesuai antara lebar sudu dengan daya air yang tersedia dimana kondisi itu akan menghasilkan efisiensi turbin yang maksimum.

\section{Kesimpulan}

Berdasarkan pengujian, pengolahan data dan pembahasan yang telah dilakukan, maka hasil penelitian ini dapat disimpulkan bahwa lebar sudu mangkok mempengrauhi kinerja dari turbin kinetik dimana lebar sudu mangkok $10 \mathrm{~cm}$ memiliki kinerja lebih tinggi dari lebar sudu mangkok $9 \mathrm{~cm}$ dan $8 \mathrm{~cm}$. Kinerja tertinggi turbin kinetik pada variasi lebar sudu mangkok $10 \mathrm{~cm}$ diperoleh pada kondisi putaran $80 \mathrm{rpm}$ dan debit $0,018 \mathrm{~m}^{3} / \mathrm{s}$. Pada kondisi tersebut daya yang dihasilkan oleh turbin kinetik adalah 12,98 Watt dan efisiensinya 35,72 $\%$.

\section{Referensi}

[1]. Kementrian ESDM RI. 2017. Statistik Ketenaga Listrikan Indonesia, Jakarata.

[2]. Maidangkay, A. Soenoko, R \& Wahyudi, S. (2014). Pengaruh Sudut Pengarah Aliran dan Jumlah Sudu Radius Berengsel Luar Roda Tunggal Terhadap Unjuk kerja Turbin Kinetik. Jurnal Rekayasa Mesin. 5 (2): 149-156

[3]. Lago, L.I. Ponta, F.L. Chen, L. (2010) Advances and Trends in hydrokinetic turbine systems. Energy for sustainable development 14 (4) 287-296.
[4]. Soenoko, R. Rispiningtati, \& Sutikno, D. (2011). Prototype of a Twin Kinetic Turbine Performance as a Rural Electrical Power Generation. Journal of Basic and Applied 1 (10): 1686-1690.

[5]. Pietersz, R. Soenoko, R. \& Wahyudi, S. (2013). Pengaruh Jumlah Sudu Terhadap Optimalisasi Unjuk kerja Turbin Kinetik Roda Tunggal. Jurnal Rekayasa Mesin. 4 (3): 220226.

[6]. Ohoirenan, W. (2012). Pengaruh Variasi Jumlah Sudu Mangkok Terhadap Unjuk kerja Turbin Kinetik Roda Tunggal. Malang: Universitas Brawijaya.

[7]. Yani, A. (2012). Pengaruh Variasi Panjang Sudu Mangkok Terhadap Unjuk kerja Turbin Kinetik. Malang: Universitas Brawijaya.

[8]. Irawan,. (2012). Pengaruh Variasi Sudut Sudu Mangkok Terhadap Unjuk kerja Turbin Kinetik. Malang: Universitas Brawijaya.

[9]. Anam, A. Soenoko, R. \& Widhiyanuriyawan, D. (2013). Pengaruh Variasi Sudut Input Sudu Mangkok Terhadap Unjuk kerja Turbin Kinetik. Jurnal Rekayasa Mesin. 4 (3): 199-203.

[10]. Yani, A. Mihdar. \& Erianto, R. (2016). Pengaruh Variasi Bentuk Sudu Terhadap Unjuk kerja Turbin Air Kinetik. Journal teknik mesin Univ. Muhammadiyah Metro (TURBO). 5 (1): 8 - 13

[11]. Bono \& Indarto. (2008). Karakteristik Daya Turbin Pelton Mikro Dengan Variasi Bentuk Sudu. Seminar Nasional Aplikasi Sains dan Teknologi: 187-196. Yogyakarta: IST AKPRIND. 
[12]. Rusman,. (2012). Pengaruh Variasi Sudut Pengarah Aliran Terhadap Unjuk kerja Turbin Kinetik. Malang: Universitas Brawijaya.

[13]. Brian \& Kirke, (2007). Vertical Kinetik Turbine Optimization. The University of Southern Australia.

[14]. Himran, S. (2017). Turbin Air. Yogyakarta:ANDI. 